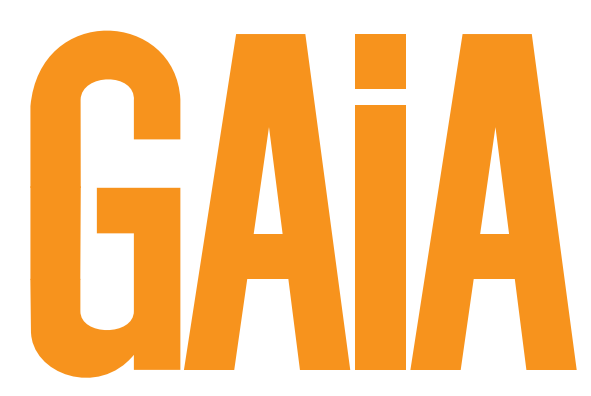

$2 \mid 2016 \begin{aligned} & \text { ECOLOGICAL PERSPECTIVES FOR SCIENCE AND SOCIETY } \\ & \text { ÖKOLOGISCHE PERSPEKTIVEN FÜR WISSENSCHAFT UND GESELLSCHAFT }\end{aligned}$

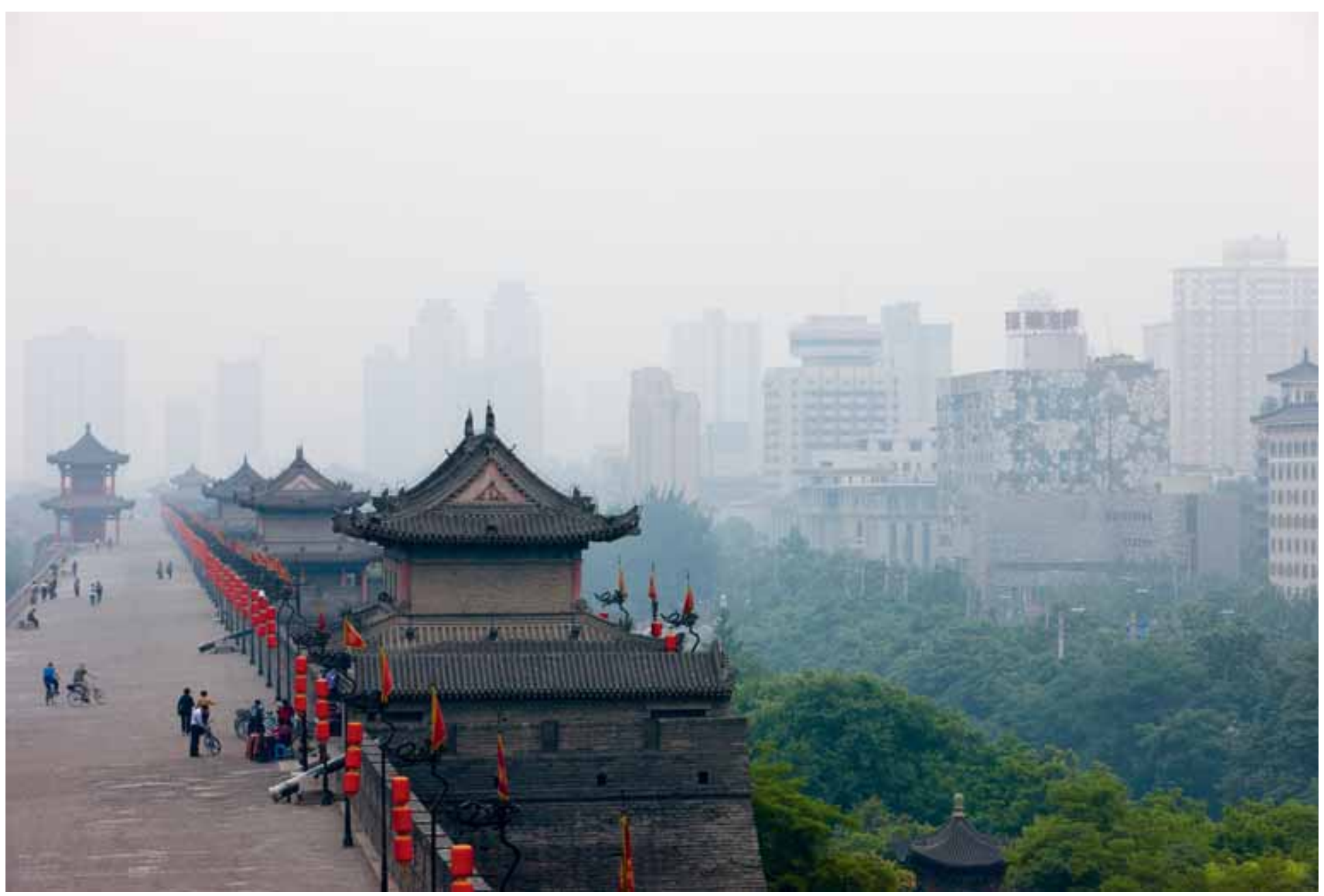

FORSCHUNG FÜR UND ÜBER TRANSFORMATION

- FRACKING UND LANDSCHAFT

- NACHHALTIGKEIT ALS FORM DES NIESSBRAUCHS 


\section{Urban Agriculture: Passing Fad or New Prospects for Agriculture and Cities?}

saguf

schweizerische akademische gesellschaft für

umweltforschung und ökologie

societé académique suisse pour la recherche

sur l'environnement et l'écologie

swiss academic society for

environmental research and ecology

Heidrun Moschitz, Christoph Kueffer

While urban agriculture might be considered a passing fad,

we argue that it is a vehicle to deal with many urgent topics

of societal transformation towards a sustainable future.

We discuss the potential of urban agriculture

to change agriculture and urban life.

Urban Agriculture: Passing Fad or New Prospects for Agriculture and Cities? | GAIA 25/2 (2016): 128-130

Keywords: city, rural, societal transformation, urban agriculture

rban agriculture has recently become a prominent topic with broad media coverage. The initial period of growth being over, the question remains whether urban agriculture will have a long-term effect on agriculture and urban life. Indeed, city administrations integrate (urban) agriculture into their planning strategies. Agricultural actors, in turn, hope that the growing interest in and engagement with urban agriculture open new opportunities for agriculture, a sector which currently faces major economic, cultural and ecological challenges.

Contact authors: Dr. Heidrun Moschitz | Research Institute of Organic Agriculture (FiBL) | Department of Socio-Economic Sciences | Frick | Switzerland | E-Mail: heidrun.moschitz@fibl.org

Prof. Dr. Christoph Kueffer | HSR Hochschule für Technik Rapperswil | ILF - Institute for Landscape and Open Space | Rapperswil | Switzerland | E-Mail: christoph.kueffer@hsr.ch

Contact saguf: Dr. Claudia Zingerli | saguf Office | ETH Zürich | D-USYS/CHN | Universitätstr. 22 | 8092 Zurich | Switzerland |

E-Mail: saguf@env.ethz.ch | www.saguf.ch

(C) 2016 H. Moschitz, C. Kueffer; licensee oekom verlag. This is an article distributed under the terms

of the Creative Commons Attribution License (http://creativecommons.org/licenses/by/3.0), which permits unrestricted use, distribution, and reproduction in any medium, provided the original work is properly cited.
We introduce a new working group (AG) of the Swiss Academic Society for Environmental Research and Ecology (saguf) that networks urban agriculture experts from the French- and German-speaking parts of Switzerland. ${ }^{1}$ A key interest of the AG Urban Agriculture is to determine how urban agriculture might initiate changes in rural and urban areas, thus contributing to a sustainable transformation of society (Zingerli and Kueffer 2016): how does urban agriculture stimulate debates about the future of agriculture in Switzerland, and which new perspectives does urban agriculture provide for the future of Swiss cities? We illustrate a state-of-the-art definition of urban agriculture with examples that were discussed in the AG, and which show the range of ongoing urban agriculture initiatives in Switzerland.

\section{What Is Urban Agriculture?}

A generally accepted definition of urban agriculture is still lacking. The recently completed COST Action Urban Agriculture Europe suggests the following definition: "Urban agriculture spans all actors, communities, activities, places, and economies that focus on biological production in a spatial context, which - according to local standards - is categorized as 'urban'. Urban agriculture takes place in intra- and peri-ur- ban areas, and one of its key characteristics is that it is more deeply integrated in the urban system compared to other agriculture. (...) It is integrated into the social and cultural life, the economics, and the metabolism of the city" (Vejre et al. 2015, p. 21). Urban agriculture thus cannot be defined by only one dimension, such as the mere proximity of farmland to a city. While this is one criterion to distinguish "urban" from "rural" agriculture, other relevant dimensions are the function(s) it fulfils, the motivation that drives farmers and gardeners to carry out agricultural activities, the market that is supplied with by the farms (local or national/global), the origin of the land used for agriculture (traditional farmland or urban areas converted into farmland), and the actors who actually do agriculture. In all of these dimensions urban agriculture is characterised by a diversity that is often much higher than in rural agriculture (Simon-Rojo et al. 2015).

The deliberately broad definition embraces a continuum of gardening and farming practices, actors, and policy contexts. Examples range from traditional, commercial farms that are situated within urban areas, often because the cities have expand-

1 www.urbanagriculture.saguf.ch 
ed to include formerly rural areas, to community-based urban gardening projects that are often run by non-traditional agricultural actors, not trained in agriculture, and sometimes with food production not being their primary goal. The latter might consider urban agriculture projects an opportunity to strengthen neighbourhoods or multicultural interactions, to experiment with new forms of locally based economies, or a means of challenging unsustainable food production and consumption. For an overview of the different types of urban agriculture see Simon-Rojo et al. (2015).

\section{New Perspectives for Swiss Agriculture}

Urban agriculture opens various pathways for a renewed dialogue between agriculture and society. This is necessary in order to transform the practice and the policy of traditional agriculture that faces increasing challenges due to environmental degradation, climate change, and economic pressure. Urban agriculture has to some extent the potential to reclaim land lost to urbanisation, and it introduces new social and economic forms of food production and relationships between food producers, intermediaries, and consumers. For instance, new economic opportunities might emerge through reduced costs for distribution and marketing, a higher willingness to pay as consumers build a direct relationship with farmers, and new business models through multi-purpose agriculture (e.g., offering outdoor experiences to children). Some examples are listed below.

The project of an urban community garden in Basel was started by a group of energetic young people on a small plot in the middle of the city, surrounded by apartment blocks. ${ }^{2}$ Over time, more people joined the project and - by collaborating in gardening - they learned about food and food production. Eventually, new projects were initiated which involved additional people; e. g., cooking classes teaching seasonal cooking, or a food cooperative. Thanks to broad media coverage, traditional farmers around the city learned about the community garden; however, interactions between them and urban community gardening project have so far been rare.

A farm that used to be in the country- side but has been integrated into the agglomeration of Zurich by urban sprawl represents a second type of urban agriculture. Although the farmer does not describe himself as an "urban farmer", he understands that consumers perceive him as such. In fact, he has built his whole business model around the opportunities given by the proximity to the city. Through a diversified management strategy, the farm produces organic vegetables, employs handicapped people, and offers the orchid glasshouse for events such as weddings. All of these activities benefit from the proximity to the city; besides, they have triggered discussions with farming colleagues and neighbours about the future of agriculture.

A third example of urban agriculture are local farms that are organised as so-called community-supported agriculture. In the 1980s, this model emerged in Switzerland, and currently experiences a revival with an increasing number of such businesses in or near Swiss cities. ${ }^{3}$ It integrates consumers into its business decisions, thus creating a close relationship between production and consumption. Consumers pay for a fixed share of the estimated production at the beginning of the growing season, then they regularly receive boxes with their share of produce. So, production risks are shared between producers and consumers; moreover, producers and consumers learn about their respective needs and expectations.

\section{New Prospects for Swiss Cities}

The Raumkonzept Schweiz (the guiding strategic document for spatial planning in Switzerland) clearly distinguishes between the urban and the rural: urban areas are defined as "productive and dynamic places of economic development, innovation, and culture" whereas rural areas are defined as places of "food production, landscape preservation, and energy production" (Schweizerischer Bundesrat et al. 2012, p. 25). However, as a result of urbanisation, many farms and rural communities that used to be situated in the countryside now find themselves surrounded by cities and agglomerations. Already over 28 percent of all agricultural holdings in Switzerland are on land classified as urban (BFS 2012). A growing role of agriculture in urban ar- eas, alongside a growing demand for urban land for farming, will challenge urban spatial planning - a sector that is not well prepared for this new type of land use. However, addressing urban agriculture as part of comprehensive city food planning can render many benefits (Morgan 2013, Sonnino 2009). Food is connected with a wide range of municipal and regional policy areas: from land-use planning to infrastructure and transport, environmental conservation, housing, economic development. Food, then, can be a vehicle to integrate the economic, social, and environmental dimensions of sustainability, as well as to address justice and health issues in cities (Moragues et al. 2013). With three quarters of the Swiss population living in cities, the challenge of solving the question of sustainable food cannot be left to the "rural".

In Lausanne, for instance, the city administration decided to use school catering to promote local food production and food sovereignty. Thereby, the local economy, including farmers within the city region, is supported, and links between the city and its hinterland are strengthened. Urban agriculture also offers a wide spectrum of opportunities for children and adults to learn about food production; therefore, integrating urban agriculture in the curriculum of schools is a promising way to encourage a sustainable and healthy diet. Other projects, such as school on a farm ${ }^{4}$ or garden kid ${ }^{5}$, have been launched. Yet, a more targeted city planning, integrating various options of food education including different forms of urban agriculture (business-oriented farms, community gardens, allotment gardens, school gardens) is still lacking.

Some Swiss cities have begun to integrate agriculture into planning schemes for the maintenance of green spaces. The demand for green spaces and nature experiences in cities is growing parallel to the growing demand for built infrastructure and a trend towards densification of cities.

\footnotetext{
2 http://urbanagriculturebasel.ch/project/ permakultur-gemeinschaftsgarten-landhof

3 www. regionalevertragslandwirtschaft.ch, http://fracp.ch

4 www.schub.ch

5 www.gartenkind.ch
} 
These approaches work at different spatial scales from individual neighborhoods to the whole city, and sometimes include the periurban spaces surrounding cites. In Geneva, for instance, the agglomeration project is planning a public park that is combining recreational space with agriculture (figure 1) (Salomon Cavin and Mumenthaler 2015).

\section{Connecting Research on Urban Agriculture}

Switzerland, especially the Swiss lowlands, is an interesting model for discussing urban agriculture. Within a small area, urban and rural life interact in a heterogeneous mosaic. Rapid urbanisation challenges the traditional separation between mostly conservative and locally-rooted rural communities and leftist and liberal urban areas with an international orientation. In recent years, research projects on urban agriculture have started at many universities and research institutions in Switzerland. Research topics include: agroecological aspects of farming, economic analyses of the supply chain, policy impact and sociocultural dimensions of different types of urban farming projects. The AG Urban Agriculture was initiated to better connect these initiatives, and brings together experts from universities, universities of applied sciences, and research and advisory institutions. The purpose of the AG is to promote scientific knowledge as well as public recognition of urban agriculture in Switzerland. The AG believes that urban agriculture is more than a passing fad - it is a vehicle to deal with many urgent topics of societal transformation towards a sustainable future. When we talk about and practice urban agriculture we simultaneously address community building, food production, food sovereignty, maintenance of green spaces in dense cities; and reconnection between the urban and the rural, between consumption and production, creating partnership along the food supply chain rather than increasing competition. Some of the questions discussed by the AG are:

- Will urban agriculture lead to substantial sociocultural changes of farming communities in Switzerland? Will this lead to new relationships between urban and rural farming communities, and will there be new opportunities to bridge the gap between rural and urban areas in Switzerland?

- What is the potential of urban agriculture as a new business model for farming in Switzerland? To which extent can the potential for innovative business opportunities be used by farmers (of the traditional and the new type)?

- How can competing demands for public green space in cities be satisfied (e. g., recreational activities, biodiversity, climate regulation, farming) and what role does urban agriculture play in these negotiations for urban space?

- Will cities manage to develop overarching food policies that integrate urban agriculture as one main aspect of connecting society with health, community, and the environment?

FIGURE 1: The project of the agro-urban park Bernex in Geneva comprises a small demonstration farm integrated into public green space within the built-up zone, and a shop selling the local agricultural products. It is expected to be established within the next few years.

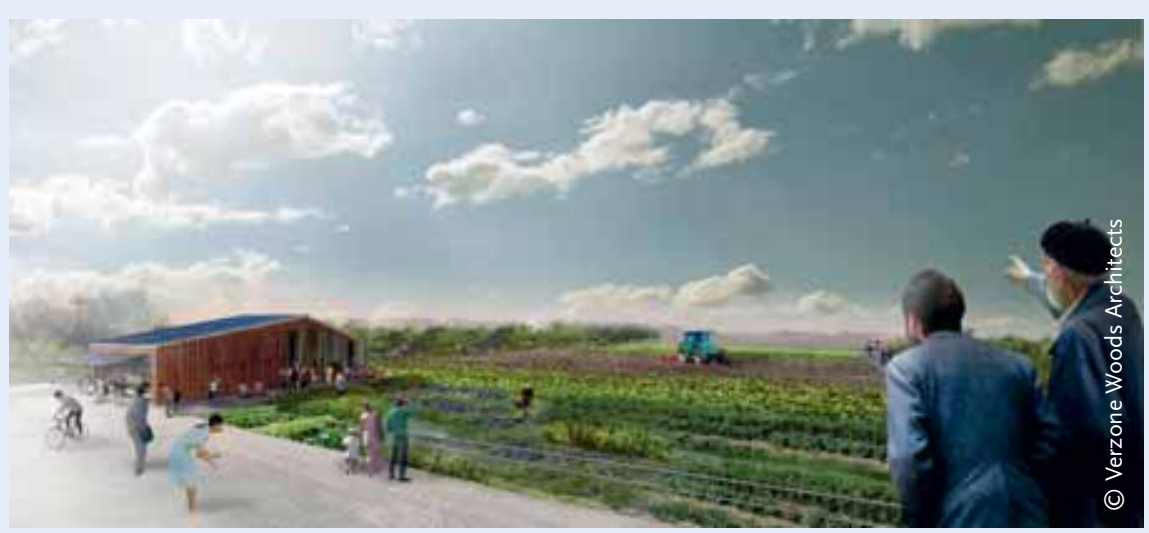

\section{saguf-Jahrestagung 2016:} Urbane Agrikultur - Impulse für eine nachhaltige Transformation von Stadt und Land

22. November 2016, Biel

Plattform für Akteure in Urbaner Agrikultur aus Theorie und Praxis: Vertreter(innen) zivilgesellschaftlicher Initiativen, aus Stadt-/Kantonsverwaltungen, Landwirtschaft und Forschung. Diskussion der Möglichkeiten und Potenziale, die Urbane Agrikultur für die nachhaltige Entwicklung von Städten und Landwirtschaft bietet.

WEITERE INFORMATIONEN: www.saguf.ch

New members are welcome to join the AG. The next opportunity to discuss these questions is the saguf annual symposium 2016 (see box).

We thank David Bourdin, Jérémie Forney, Ingrid Jahrl, Cyril Mumenthaler, Joëlle Salomon Cavin and Hans Wydler for their contributions, as well as Janine Bolliger and Claudia Zingerli for valuable comments.

\section{References}

Bundesamt für Statistik (BFS). 2012. Landwirtschaftliche Strukturerhebung 2012. Neuchâtel: BFS.

Moragues, A. et al. 2013. Urban food strategies: The rough guide to sustainable food systems. Document developed in the framework of the FP7 project FOODLINKS (GA 265287). www.food linkscommunity.net (abgerufen 02.06.2016).

Morgan, K. 2013. The rise of urban food planning. International Planning Studies 18/1:1-4.

Salomon Cavin, J., C. Mumenthaler. 2015. Geneva. Agriculture integrated into urban planning? A challenge. In: Urban agriculture Europe. Edited by F. Lohrberg, L. Lička, L. Scazzosi, A. Timpe. Berlin: Jovis. 157-163.

Schweizerischer Bundesrat, Konferenz der Kantonsregierungen, Schweizerische Bau-, Planungs- und Umweltdirektoren-Konferenz, Schweizerischer Städteverband, Schweizerischer Gemeindeverband. 2012. Raumkonzept Schweiz. Überarbeitete Fassung. Bern: Schweizerischer Bundesrat.

Simon-Rojo, M. et al. 2015. Chapter 1.2: From urban food gardening to urban farming. In: Urban agriculture Europe. Edited by F. Lohrberg, L. Lička, L. Scazzosi, A. Timpe. Berlin: Jovis. 22-28.

Sonnino, R. 2009. Feeding the city: Towards a new research and planning agenda. International Planning Studies 14/4: 425-435.

Vejre, H. et al. 2015. Chapter 1.1: Can agriculture be urban? In: Urban agriculture Europe. Edited by F. Lohrberg, L. Lička, L. Scazzosi, A. Timpe. Berlin: Jovis. 18-21.

Zingerli, C., C. Kueffer. 2016. Eine große Transformation der Schweiz: Auf Bewährtes setzen und mit Neuem experimentieren. GAIA 25/1: 64-66. 